$2-2019$

BEPS and the Emerging Global Approach to Taxing Multinational Enterprises

Jinyan Li

Jin Bao

Huaning (Christina) Li

Follow this and additional works at: https://digitalcommons.osgoode.yorku.ca/conference_papers Part of the Tax Law Commons 


\title{
BEPS and the Emerging Global Approach to Taxing Multinational Enterprises
}

\author{
Jinyan Li,* Jin Bao** and Huaning (Christina) $\mathrm{Li}^{* * *}$ \\ Re-Imagining Tax Policy for the $21^{\text {st }}$ Century: Inspired by Tim Edgar’s Scholarship \\ February 8-9, 2019 \\ Toronto, Canada \\ *Professor of Law, Co-director, LLM Taxation, Osgoode Hall Law School, York University \\ ** Second-year JD student, Osgoode Hall Law School, York University \\ *** Ph.D. candidate, Osgoode Hall Law School, York University
}


Contents

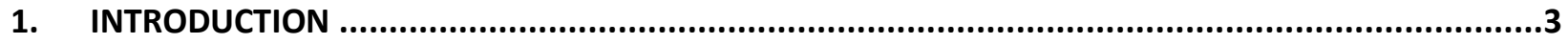

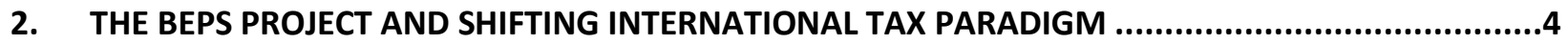

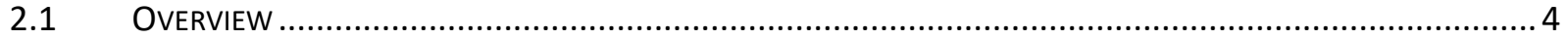

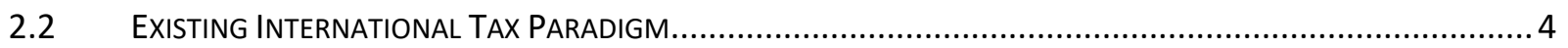

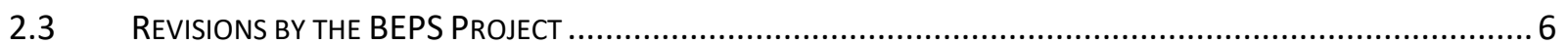

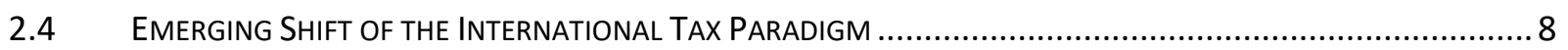

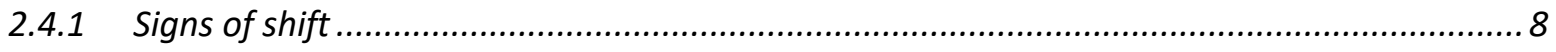

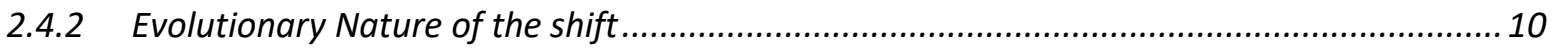

2.4.3 Unilateralism in action and challenges ahead ............................................................. 11

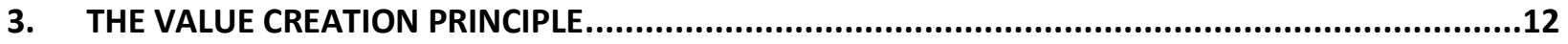

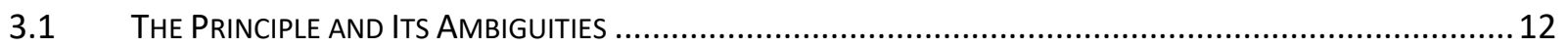

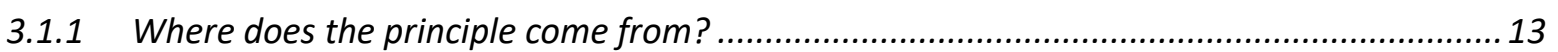

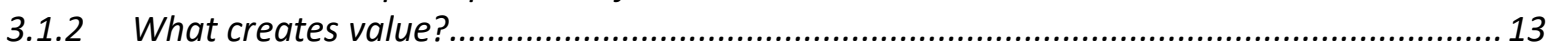

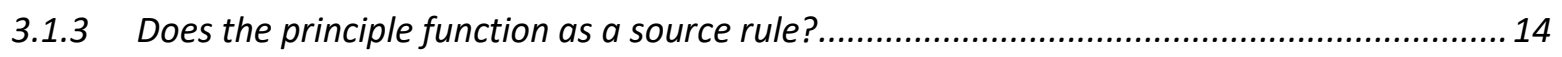

3.1.4 What is the relationship to the arm's length principle?................................................... 15

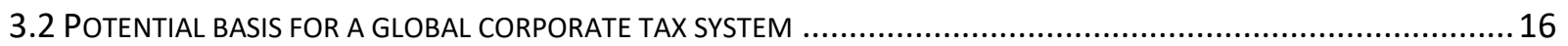

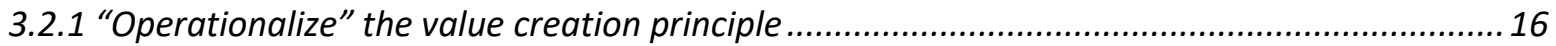

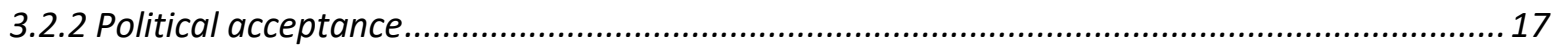

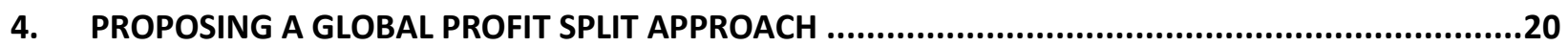

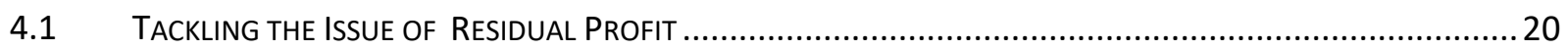

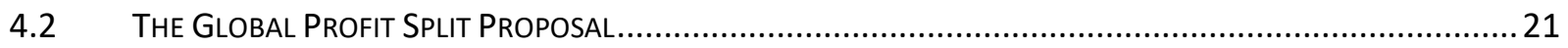

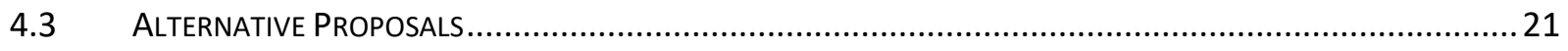

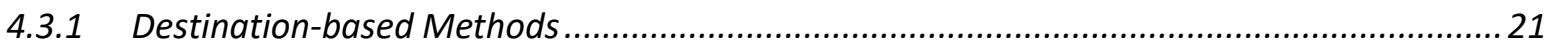

4.3.2 Alternative minimum tax on global profits ....................................................................... 23

4.3.3 Reversing the residence-source paradigm ........................................................................ 24

4.3.4 The CCCTB - Multi-factor Formulary apportionment ...................................................... 25

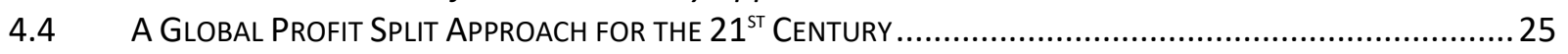

4.4.1 Consistency with the value creation principle ................................................................26

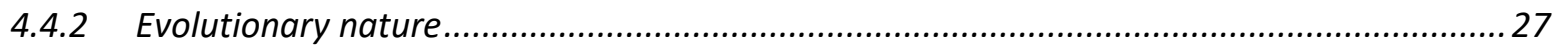

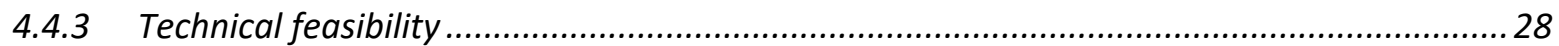

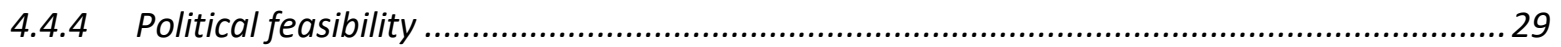




\section{INTRODUCTION}

The G20/OECD Base Erosion and Profit Shifting (BEPS) Project aimed at revising existing tax rules to align the taxation of profit with the location of economic activities and value creation (the “value creation principle”). It has received much commentary in literature and general debates ${ }^{1}$ and has been regarded as "the most significant re-write of the international tax rules in a century", ${ }^{2}$ an opportunity to "rebuild a healthy scheme for allocating taxation rights", ${ }^{3}$ having the potential to significantly alter the contours of the international tax regime, ${ }^{4}$ transforming the international tax regime, ${ }^{5}$ signaling a "new struggle over international taxation", ${ }^{6}$ or representing the "emergence of a new international tax regime". ${ }^{7}$ The OECD claimed that the revised rules represent "the first substantial - and overdue - renovation of the international tax standards in almost a century". ${ }^{8}$

In this paper, we suggest that the ambitious BEPS Project ${ }^{9}$ represents a shift from a bilateral system to a multilateral global system of taxing multinational enterprises (MNEs). We further argue that the misconceived and controversial "value creation principle” may have a fighting chance of being the basis for the global tax system in the $21^{\text {st }}$ Century. We propose a global profit split approach allocating MNEs' global profits to countries where value is created and explain the pros and cons of this proposal.

The scope of this paper is limited to the impact of the BEPS project on the allocation of MNEs's global profits among countries for tax purposes. It does not consider the general corporate tax issues, such as tax rate and integration of corporate tax and personal income tax, which, we believe, will continue to be defined by domestic fiscal policies. It also does not dwell into the jurisdictional nexus issue, even though the tax presence (physical, economic or digital) of an MNE in a country can be unclear in some cases, such as digital businesses.

The structure of the paper is as follows. Following the Introduction, Part 2 provides an overview of the BEPS Project and signs of shifting international tax paradigm towards a global approach. Part 3 discusses the value creation principle and its implications for the emerging global tax approach. Part 4 proposes a global profit split approach to allocating MNEs' global profits and compares it to other proposals. It makes the case that the global profit split approach can be 
designed to reflect the value creation principle, although significant challenges exist, and has a chance of being implemented by countries in the $21^{\text {st }}$ century.

\section{THE BEPS PROJECT AND SHIFTING INTERNATIONAL TAX PARADIGM}

\subsection{Overview}

The Base Erosion and Profit Shifting (BEPS) Project began in July 2013 when OECD and G20 countries agreed on the need for multilateral efforts to tackle the problem of BEPS. ${ }^{10}$ "BEPS refers to tax planning strategies that exploit gaps and mismatches in tax rules to artificially shift profits to low or no-tax locations where there is little or no economic activity." 11 BEPS is problematic from the perspective of G20 and OECD countries because it causes the loss of tax revenue, ${ }^{12}$ "undermines the fairness and integrity of tax systems" and undermines "voluntary compliance by all taxpayers". ${ }^{13}$ Addressing the BEPS problem and "ensuring that all taxpayers pay their fair share of taxes is more than ever a priority" in those countries in the context of "severe fiscal consolidation and social hardship” following the 2008 global financial crisis. ${ }^{14}$ In other words, tackling BEPS practices of MNEs was politically and fiscally important.

The root cause of the BEPS problem was diagnosed to be the defective tax rules (such as gaps and mismatches in international tax rules in different countries) which allow MNEs to legally but artificially shift profits to low or no-tax jurisdictions where the business has little or no economic activity. Since the issues lie with the tax rules themselves and the goal of the BEPS Project is to "revise the rules to align them to developments in the world economy, and ensure that profits are taxed where economic activities are carried out and value is created." ${ }^{15}$ We suggest below that these rewritten rules signal a shift away from the existing bilateral international tax regime to a multilateral global regime of taxing MNEs.

\subsection{Existing International Tax Paradigm}

Under the existing international tax regime, an MNE is generally liable to tax in each country in which it has a business presence in the form of a local company or permanent establishment. The governing tax laws are domestic laws and bilateral tax treaties. International tax rules in domestic laws generally impose tax on a company that is a member of a MNE group on the basis of the company’s domestic residence or domestic source of income. For example, under the Canadian 
Income Tax Act ${ }^{16}$ (ITA), a resident company ${ }^{17}$ is taxable on its worldwide income under subsections 2(1) and (2) and section 3, while a non-resident company is taxable on its Canadian source income, such as carrying on business in Canada, realizing capital gains from disposition of taxable Canadian property or receiving interest, rent, royalty or dividends from a Canadian resident payer. ${ }^{18}$ Section 247 contains transfer pricing rules to, in effect, test the price of related-party transactions against the arm's length principle. Bilateral tax treaties typically follow the OECD Model Convention ${ }^{19}$ and/or the UN Model Convention ${ }^{20}$ and allocate taxing rights between the two countries on the basis of residence and/or source of income. Tax treaties also authorize the tax authorities to adjust the profits of an associated enterprise in accordance with the arm's length principle.

Even though the residence-source paradigm and the arm's length principle are found in the domestic law of many countries, the detailed rules to determine residence, source of income, the amount of profit for tax purposes tend to differ from country to country. Even the transfer pricing rules that tend to be informed by the OECD Transfer Pricing Guidelines are implemented differently across countries. Tax treaties “bridge” the two countries' tax systems in order to prevent double taxation, tax evasion or tax avoidance, but they do not require the domestic laws be coordinated or "synchronized". As such, there are gaps, overlaps and mismatches between domestic tax laws. Furthermore, because tax law generally defers to private law for determining the nature of transactions and private laws may differ from country to country, divergence in private laws also results in divergence of tax laws. For example, a financing transaction may be treated as debt in one country, but equity in another.

While the business of MNEs is global, tax-related information about the global business is not available to the tax authorities of any given country. Under the laws of a specific country, the obligation to file tax returns is limited to taxpayers, which are local subsidiaries or non-resident companies with a permanent establishment. For example, under the Canadian ITA, the tax reporting obligation falls on taxpayers that are liable to Part I tax (i.e. resident companies or nonresident companies carrying on business in Canada). The Canadian subsidiary of a foreign-based MNE is not required to report on the global income of the MNE group. As such, each country in which the MNE operates has partial information about the MNE's business. There is asymetry in 
tax information between MNEs and the tax authority of a country, and a serious issue of "endemic and worrying lack in data and information”. ${ }^{21}$

Taxpayers have the right to engage in tax planning and minimize their taxes. Legal fictions and legal arrangements are generally respected by tax laws; they are "ignored” or "looked through” for tax purposes only in specific circumstances. Meanwhile, countries engage in tax competition in order to attract investment by MNEs. Some countries do not even impose corporate income tax and function as "tax havens". Through tax planning strategies such as debt financing, transfer pricing, tax arbitrage and treaty shopping, an MNE can shift profits earned in production countries or market countries to entites located in tax havens where the MNE has little or no economic activity.

The existing international tax regime was created almost 100 years ago. It has evolved somewhat in technical details, but the residence-source paradigm has remained the same. Each country seeks to determine the amount of taxable income of a member of an MNE group by reference to observable evidence or activities and adheres to the principle of taxing each company as a separate enity and then rely on the arm's length principle to prevent income shifiting by members of an MNE group. Meanwhile, the business of MNEs has become global in nature and more reliant on intangible property and technology. Globalisation and digitation have exacerbated the impact of gaps and frictions among different countries' tax systems. The "web" of national tax laws encountered by an MNE has serious holes and gaps to allow its income to find its way to a tax haven.

\subsection{Revisions by the BEPS Project}

The G20 and OECD member countries represent the world's largest economies and suffer the most from MNEs' tax planning practices. Since neither the G20 or OECD has any tax law-making power and cannot actually rewrite any tax rules directly, the BEPS Project developed measures for countries to incorporate into their laws or tax treaties. ${ }^{22}$

The OECD Action Plan on BEPS (2013) ${ }^{23}$ identified 15 actions to address the root cause of BEPS by: introducing coherence in the domestic rules; reinforcing substance requirements in the existing international standards; improving information reporting and transparency; and introducing a 
multilateral instrument. ${ }^{24}$ The final reports on these actions contain recommendations, which take the form of minimum standards to be enacted into domestic law, ${ }^{25}$ updated standards, ${ }^{26}$ common approaches ${ }^{27}$ or best practices, ${ }^{28}$ depending on the level of consensus reached. ${ }^{29}$

To improve coherency, common approaches are recommended to deal with hybrid mismatch arrangements and interest deductibility. In the case of hybrid arrangements, for example, the approach is to eliminate gaps or mismatch by linking the domestic rules of different countries. ${ }^{30}$ In the case of interest deductibility, the recommended approach is based on a fixed ratio rule which limits an entity’s net deductions for interest and payments economically equivalent to interest to a percentage of its earnings before interest, taxes, depreciation and amortisation (EBITDA). The recommended corridors of possible ratios is $10 \%$ and $30 \%{ }^{31}$

The substance of taxpayers' activities (as opposed to legal form or legal arrangements) is emphasized in Actions 8-10 Report titled “Aligning Transfer Pricing Outcomes with Value Creation”. Recognizing that the arm's length principle is the cornerstone of transfer pricing rules and the existing guidance on the application of the principle has proven vulnerable to manipulation, the revised rules aim to "secure outcomes that see operational profits allocated to the economic activities which generate them”. ${ }^{32}$ They authorise the disregarding of the transactions between associated enterprises that lack commercial rationality and emphasize that the allocation of profits to risks and intangibles be based on substantive contributions in fact as opposed to contractual allocation of risks or mere legal ownership of intangibles. ${ }^{33}$

To address the tax information problem, a minimum standard on country-by-country reporting (CbCR) was introduced in Action 13. Under the CbCR standard, a MNE must fill out a master file (on a template prepared by the OECD) and files it with the country where its head office is based. The template includes information on the structure of the MNE group, the global value chains and payments made by members of the group to each other. The reporting also covers information on revenue, profit, tax paid, stated capital, accumulated earnings, number of employees and tangible assets as well as the company's overall strategy for the development, ownership and exploitation of intangibles. The master file received by the country where the head office is based is then shared with the tax authorities of the countries where the MNE has operations. 
To reduce gaps and frictions among different tax systems which are coordinated through several thousands of bilateral tax treaties, Action 15 of the BEPS Project recommended a multilateral mechanism for speedy amendment of existing bilateral tax treaties. ${ }^{34}$ A Multilateral Convention to Implement the Tax Treaty Measures to Prevent Base Erosion and Profit Shifting ("Multilateral Instrument" or "MLI") was developed and has now be signed by over 86 countries, ${ }^{35}$ including Canada. Pursuant to the MLI, Canada is able to modify its current tax treaties with countries which have also signed the MLI. The MLI includes a minimum standard on preventing treaty abuse and another minimum standard on resolving tax disputes through the mutual agreement procedure.

G20 Leaders endorsed the BEPS recommendations and strongly urged "the timely implementation of the project and encourage all countries and jurisdictions, including developing ones, to participate”. ${ }^{36}$ An inclusive framework was developed in 2016 to monitor the implementation of BEPS measures globally, ${ }^{37}$ and had over 130 countries participating by the end of December 2018. A global Platform for Collaboration on Tax was launched in April 2016 by the International Monetary Fund, OECD, United Nations and World Bank Group to provide technical assistance to interested developing economies.

\subsection{Emerging Shift of the International Tax Paradigm}

The BEPS Project signals a shift away from the existing bilateral regime of residence-source based taxation towards a multilateral regime of value-creation based taxation. Such shift is by no means clear or controversy-free. After highlighting the signs of such shift, this section points out the controversies and challenges.

\subsubsection{Signs of shift}

Signs of shift include the standard-setting institutions and processes, the adoption of the value creation principle, recognizing the global nature of MNEs' businesses, introducing a global standard for tax reporting by MNEs and information sharing by governments, establishing a global monitoring mechanism for implementation, and introducing a multilateral legal instrument that affects or backstop the distribution of taxing powers among countries.

"For the first time all OECD and G20 countries have worked together on an equal footing to design common responses to international tax challenges.” ${ }^{38}$ In the past, international tax standards (or 
soft law) had been developed by the OECD and developed countries. The BEPS project involved more countries (notably emerging countries such as China, India, Russia, etc.) and international organizations, including the African Tax Administration Forum, IMF, the World Bank and the United Nations. The problems of BEPS were considered "global” in nature and BEPS Project sought to avoid having competing sets of international standards which could lead to "global tax chaos". 39

The BEPS Project took a more "global” view of MNEs and emphasized taxing MNEs in accordance with the value creation principle. In effect, this approach renders the existing residence-source paradigm virtually irrelevant to taxing MNEs. For example, BEPS Action 4 (interest deduction) Action 13 (CbCR) and Actions 8-10 (transfer pricing) provide signals of treating MNEs as global firms. The EBITSA or EBIT rule in Action 4 takes into account the worldwide MNE group's interest-to-EBITDA ratio. The CbCR requires the filing of a "master file” which contains information on the MNE group. Profit split methods under the updated trahsfer pricing rules take into account of a MNE’s global value chain analysis.

Bilateral tax treaties are being amended through a multilateral legally-binding instrument. So, tax rules in both domestic law and tax treaties are now more global. Tax administrations have access to tax information through a global mechanism. ${ }^{40}$

The BEPS Project and related initiatives, such as the common reporting standard and global information sharing platforms increased the legal obligation of MNEs to report tax information and the capacity of tax authorities to obtain information. The Inclusive Framework has some promise of actually ensuring “widespread and consistent implementation” of new international tax standards. ${ }^{41}$

Overall, the BEPS Project is signaling a shift towards a global approach for taxing MNEs. Such shift was an reaction to the tax problems arising from global financial crisis and fundamental challenges posted by globalization and digitation to the existing international tax regime created for an industrial, physical economy. The shift amplified by the BEPS, but there were earlier undercurrents of shifting. 


\subsubsection{Evolutionary Nature of the shift}

Recent shift away from the traditional international tax paradigm was motivated by addressing the fundamental mismatch between the paradgim and the new realities of a global digital economy, the rise of MNEs, and the global power shifts away from the United States and the OECD.

The OECD has been the main caretaker of international tax standards and a "global tax policeman” 42 in recent decades. For example, the OECD Model Tax Convention and Commentaries as well as the OECD Transfer Pricing Guidelines are important sources of "soft law”. To minimize the negative effects of harmful tax competition, which was regarded as an “emerging global issue" in the $1990 \mathrm{~s}^{43}$ the OECD launched an initiative in 1998 to establish a multilateral approach to tackle this issue so that countries could operate individually and collectively to limit the extent of these harmful practices. The OECD also led initiatives in tackling the tax challenges of e-commerce and digital businesses and creating the Global Forum on transparency and exchange of information for taxation. ${ }^{44}$ The shifting of global geopolitical power towards the G20 brings with it the shifting of power in setting international tax standards. As a group, non-OECD members of the G20 have different preferences about how the international tax system should be reshaped as the existing system better serves the interests of OECD countries. ${ }^{45}$ The rise of MNEs and the perception of lack of fairness in the existing system of taxing MNEs goes beyond the allocating of taxing rights between countries. At taxpayers' level, the ability of MNEs to minimize their taxes was perceived to be unfair, resulting in erosion of public confidence in the tax system. Further, corporate income tax has at least two important functions in democratic countries: it raises revenue to finance public spending, including social programs; it backstops progressive personal income tax to ensure progressive taxation, which is the main means of redistributing social income. Therefore, corporate tax avoidance weakens these two functions and has a direct impact on welfare of citizens. The 2008 Global Financial Crisis helped exposing the link between tax avoidance and social welfare. The public exerted political pressure on governments to prevent erosion of their welfare by MNEs.

At a technical level, through the efforts of the OECD and the United Nations, transfer pricing rules have evolved towards more substance-based analysis in recent years and developing countries 
have demanded more source-based taxing rights. The most recent example of the latter is the new provision on service fees in Article 12A of the UN Model Convention. ${ }^{46}$

\subsubsection{Unilateralism in action and challenges ahead}

The signals of shift towards a global approach to taxing MNEs are by no means universal. In fact, judging by the actions taken by some countries, unilateralism is very much at play. It is true than many BEPS recommendations have been implemented by many countries. For example, over 100 countries (including most EU patent box countries ${ }^{47}$ ) have committed to implementing BEPS Action 5 (Countering Harmful Tax Practices More Effectively, Taking Into Account Transparency and Substance). Of the 175 preferential tax regimes reviewed by the Forum on Harmful Tax Practices, 31 regimes have been changed; 81 regimes require legislative changes which are in progress; 47 regimes have been determined to not pose a BEPS risk; 4 have harmful or potentially harmful features and 12 regimes are still under review. ${ }^{48}$

However, implementation of other BEPS Measures varies greatly. Some OECD countries which suffer from sophisticated tax planning using hybrid instruments or entities or financing transactions have implemented the common approaches recommended in Action 2 and Action 4. Examples are the adopt of EBITDA in the EU, USA, Australia, and South Africa, and hybrid rules in Australia, France, Germany and UK. ${ }^{49}$ In the case of developing countries, implementation is more limited, for several possible reasons. The BEPS Measures were not designed to deal with the issues faced by developing countries, ${ }^{50}$ even though substantial efforts were made to take the viewpoints of developing countries into account by the BEPS Project. Developing countries are primarily concerned with the erosion of source-based taxation (through transfer pricing, avoidance of permanent establishment status, or treaty shopping and avoidance of taxation of service fees or capital gains of non-residents from offshore indirect sales). They also have limited capacity to respond to BEPS problems. ${ }^{51}$ Not surprisingly, developing countries have generally chosen to implement Actions 8-10 and 13 on transfer pricing. ${ }^{52}$

Meanwhile, unilateral actions have been taken by countries in the name of combatting BEPS. Some are legislative, including the diverted profit tax in the United Kingdom and Australia, ${ }^{53}$ GILTI rules in the United States, ${ }^{54}$ equalization levy in India, digital services tax in the UK. ${ }^{55}$ Tax auditors in many countries have been reportedly emboldened by the BEPS Project and taken an 
aggressive stance against foreign MNEs. For example, the number of tax controversies has risen in Asia and other countries. ${ }^{56}$

The difficulties facing a shift to a global approach to taxing MNEs are evident in the process of developing consensus in taxing digital businesses. The BEPS Project did not contain a final report on Action 1 regarding digital economy. There are ongoing concerns around the ability of the existing tax rules (including the revised rules) to meet the needs of a rapidly digitalising economy. At the request of the G20 Finance Ministers, the Inclusive Framework issued the "Interim Report on the Tax Challenges Arising from Digitalisation” in March 2018. The Interim Report ${ }^{57}$ still contains no consensus-based measures to tackle the broader tax issues, after analyzing a number of options, including some domestic legislative measures. According to the report, there was no consensus on whether new rules are needed and if so, whether the new rules should apply only to digital businesses (ring-fencing). There was also no consensus on whether users create value and if so, how much value is created. Work continues towards a consensus-based, global solution by $2020 .^{58}$

\section{THE VALUE CREATION PRINCIPLE}

A paradigm shift towards a global approach to taxing MNEs faces many challenges, including political, institutional, legal and administrative challenges. A unifying principle to guide the allocation of taxing rights over MNEs' global profits would be critical. Is the value creation principle such a principle? In this section, we briefly discuss the meaning, scope and role of this principle.

\subsection{The Principle and Its Ambiguities}

The BEPS Project's stated goal to "revise the rules to align them to developments in the world economy, and ensure that profits are taxed where economic activities are carried out and value is created" 59 has been regarded as introducing the value creation principle. ${ }^{60}$ "The ascendency of the value creation principle has been remarkable, as has its influence." ${ }^{61}$ However, the BEPS Project did not elaborate on the meaning of "value creation" and the principle suffers from significant ambiguities. 


\subsubsection{Where does the principle come from?}

The notion of "value creation" itself is "new" in international tax discussions, except in regard to transfer pricing issues associated with intangibles. There is no single provision in the OECD Model Convention and existing tax treaties that can be identified as referencing, explicitly or implicitly, to value creation. Similarly, there is no existing international tax provisions in the Canadian Income Tax Act that refers to value creation.

The existing international tax system distributes taxing rights between countries on the basis of residence and source. Neither residence or source is explicitly linked to the place of value creation, although they might be originally used as proxies for measuring the "ability to pay" or the host country’s “contribution” to the corporate taxpayer’s income-earnign activities. ${ }^{62}$

There is no clear theoretical underpinning of the value creation principle. The BEPS Project does not reject the theories that support the existing system, that is, the economic allegiance theory, the benefit theory, the neutrality theory. ${ }^{63}$ Therefore, the value creation principle could be viewed as a new interpretation of existing theories. This is perhaps most obvious in the debates about taxing digital businesses. For example, the UK government views the participation and engagement of users as an important aspect of value creation for digital business, and the location of users in the UK could be read as that the non-resident digital business companies owe "economic allegiance" to UK as they derive benefits from the infrastructure provided by the UK. ${ }^{64}$

\subsubsection{What creates value?}

What creates value for tax purposes? Some clues may be gleaned from the BEPS reports. For example, the reports on digital economy mention user and/or customers as potential value drivers in digital businesses. The Master (global) File and Local (country) file required by the CbCR reporting ${ }^{65}$ mention important drivers of business profit, such as key functions performed, important risks assumed, and important assets used, for the development, ownership and exploitation of intangibles, central financing function for the group. ${ }^{66}$

The BEPS Project seems to suggest that the notion of value creation refers to the value or profit generated by the activities of a MNE group (that is, the supply side). ${ }^{67}$ Financial accounting data for the MNE group and a local entity is an important source of information for determining profits. 
However, in allocating the group profit to a specific country, "demand side” factors, such as "local market features”, including location savings and consumer preferences or market premium, can be relevant factors in comparability analysis and splitting residual profit of the group. ${ }^{68}$ Some commentators suggest, however, that value realization through sales or marketization of goods and services also create value. ${ }^{69}$

\subsubsection{Does the principle function as a source rule?}

There are concerns about establishing rules to implement the value creation principle. ${ }^{70}$ Can it become a source rule? The debates about digital taxation seem to suggest that the principle can be a source rule to justify the taxation of remote digital businesses on the basis of a digital presence. Since the BEPS Project does not elaborate what the "base" in "base erosion and profit shifting" is and invokes anti-avoidance rules to protect the tax base, it can be assumed that BEPS Project regarded the value creation principle as the basis for establishing the existing tax base. This is consistent with the rewriting objective of the BEPS project. In this sense, the value creation principle plays a role of the benefit principle or even the economic allegiance theory in providing a broader rationale for a country to claim taxing right over international income.

As a territorial source rule, however, can the place of economic activities and place of value creation be separate? In the case of profit derived from intangibles, group synergies and other mobile factors, determining the location of value creation is challenging. Capital importing countries will have different perspectives from capital exporting countries. "Production” countries may disagree from market countries about the value generated by customers.

The value creation principle can be used as a negative source rule. The BEPS Project seems to rely on this principle to justify anti-abuse rules in the area of treaty shopping, permanent establishment and transfer pricing to deny taxing rights of jurisdictions where no value is created. This can be seen from the Tax Annex to the Saint Petersburg G20 Leaders Declaration (2013), which refers to this principle only in the context of these three areas. ${ }^{71}$ In the BEPS Package, the value creation principle was most relevant in Actions 8-10 on transfer pricing and Action 1 on the taxation of digital businesses based on the existence of a permanent establishment in an economic or digital sense. In effect, the value creation principle can be viewed as a negative source rule: a MNE's profit should not be considered taxable in a country where there are no economic activities or value 
creation. This is clear in the case of the revised transfer pricing rules which deny profit from being recognized in an intermediary country.

\subsubsection{What is the relationship to the arm's length principle?}

What is the relationship between the value creation principle and the arm's length principle? One view is that the value creation principle is a benchmark for testing the outcome of applying the arm's length principle. Because of "the perceived emphasis on contractual allocations of functions, assets and risks" under the existing guidance, the arm's length principle has been proven vulnerable to manipulation, leading to outcomes "which do not correspond to the value created through the underlying economic activity carried out by the members of an MNE group." 72 Therefore, the BEPS Action Plan required rewriting the guidance on the arm's length principleby emphasizing substance, economic activities, value creation as opposed to self-serving contractual and legal arrangements. As such, the value creation principle's function is of "a corrective nature" - "a method for countering abusive constructions and not as an independent new standard.”73

However, it is questionable whether the arm's length principle was intended to be refereced to value principle.

The flaws of the existing transfer price methods, which are already known, may be further burdened with flaws of the concept of value creation, of which there is only currently a limited awareness. Such a combination would give better results only if the arm's length principle could be considered to be an indirect proxy for taxation where value is created, which would sometimes have to be corrected by direct observation of the created value. However, at least historically, this has not been the purpose of the arm's length standard, which is intended to realize market neutrality between integrated and non-integrated businesses, but not necessarily in accordance with value creation. ${ }^{74}$

Another view is that the BEPS Action Plan contemplated that the value creation principle can be broader than the arm's length principle: "if transfer pricing risks remain after clarifying and strengthening the guidance, the BEPS Action Plan foresaw the possibility of introducing special measures either within or beyond the arm's length principle." (emphasis added) ${ }^{75}$ Presumably, the purpose of this approach is two-fold: removing the unnecessary debate about consistency of the revised transfer pricing measures with the arm's length principle; and setting the stage for innovative ways of better allocating global profits of MNEs among countries. This approach is 
critical to the BEPS Project because some G20 countries have different views about the arm's length principle. ${ }^{76}$ For example, China and India have taken a more holistic, global and substanceover-form approach to applying the arm's length principle. ${ }^{77}$

The point where the arm's length principle ends and the value creation principle continues is debatable. History suggests that there is a spectrum for implementing the arm's length principle, ranging from comparable transactional pricing methods to transactional profit split methods. Even though the OECD Transfer Pricing Guidelines regard formulary apportionment method to be inconsistent with the arm's length principle, opposing views exist. ${ }^{78}$ The Common Consolidated Corporate Tax Base (CCCTB) in $\mathrm{EU}^{79}$ and the proposed digital taxation measures in the UK move closer to formulary apportionment. The BEPS Project has authorized an expanded use of profit split method, especially in regard to allocating income arising from "synergistic benefits benefits of operating as a group" and "integrated global value chains." 80 It could be said that the transfer pricing regime under the value creation principle is moving closer to allocating an MNE's profit on a global basis.

\subsection{Potential basis for a global corporate tax system}

"It is now widely taken as axiomatic that the existing international corporate tax system is based on the [value creation] principle" and there also appears to be "widespread agreement, at least amongst policymakers, that the system should be based on this principle." ${ }^{1}$ Whether or not the value creation principle can be the basis for a new global approach to taxing MNEs may depend on several factors, including: (a) if the can be "operationalized" through legislation and administration on a consensus basis; ${ }^{82}$ and (b) if the principle can garnish international support. And these are big “ifs”.

\subsection{1 "Operationalize" the value creation principle}

If the value creation principle can be translated into a source rule ${ }^{83}$ for allocating the taxing rights over MNEs’ profit among countries, it could replace the current residence-source paradigm. Assuming rules can be developed for global value chain analysis and determining where and how much value is created so that a MNE's routine profits and residual profits can be allocated, there is no need for the tax system to adhere to the residence principle. MNEs would be taxed based on 
the source of income as residence is not a meaningful nexus for tax jurisdiction. The activity of incorporation does not create any value on its own. Originally, corporate residence was generally tied to the place of value-creation activities, such as headquarter functions, place of carrying on business. Recently, the use of intermediaries incorporated in no-tax jurisdictions is not accompanied by such activities. The original assumption of the linkage between legal incorporation and economic presence is no longer valid. The CFC rules already remove the tax significance of corporate residence in the case of passive income. In countries adopting the territorial system of taxation, corporate profits are already taxed on a source basis.

The value created in the country of corporate residence can be captured by the value creation principle. For capital exporting countries, the value creation activities can be entrepreneurial leadership, management and control, strategic planning, headquarter activities, providing capital, and other activities such as research and development. The value creation principle is capable of recognizing the profit derived from such activities. In many capital importing countries, MNEs use either local subsidiaries or permanent establishments to carry on the local business. As such, local residence and source of income give rise to the same level of taxing right and such right is captured by the value creation principle as well.

If a global profit split method emerges in the future to take into account of sales of goods or services, the value creation principle would lead to a more equitable distribution of taxing rights among countries than the current system.

\subsubsection{Political acceptance}

The ambiguity of the value-creation principle may be its strength in the context of the BEPS Project. It is high-sounding and makes intuitive sense. It appears to be self-explanatory to politicians and laypersons: a foreign MNE owes tax in a country in which its value is created. To put it differently, an MNE should pay tax in a country if its global value chain includes that country. For example, if Starbucks sells a great deal of coffee in the UK, it should pay UK corporate tax. At a technical level, the ambiguity may make it easier to bring tax officials and other participants with varying degrees of tax expertise together to discuss highly complex tax rules as one can justify the changes on ground of advancing this ambiguous, but high-sounding goal. 
Perhaps more profoundly, adopting the value creation principle suggests a desire for a more fundamental shift, at least on the part of some members of the G20, particularly BRICS countries, that were increasingly unsatisfied with the existing international tax system and wanted to have a voice in reshaping it. ${ }^{84}$ The traditional goal of international taxation to prevent double taxation can longer capture what these countries wish to achieve. They want to have a share of the global tax base that is greater than what is allocated to them under the existing system. They cannot achieve that goal merely through protecting the existing tax base by having better anti-avoidance measures. They can, however, have some leeway to “gain” additional tax base under the over-arching goal of taxation based on value creation. From BRICS countries' perspective, transfer pricing and permanent establishment (for both traditional businesses and digital businesses) are key problematic areas. Empirical evidence on BEPS implementation practices of BRICS and other countries would likely show that they use BEPS to achieve both "base addition" and "base protection” objectives. One would imagine that that was intended from the beginning of the BEPS Project.

As shown by the BEPS Project, commitment by political leaders of powerful countries is critical to launching the reform process and ensuring implementation. Political pressures may expedite the process and deliver outcomes that can be communicated to the general public. Moreover, valuebased discussions may lead to consensus. But, high-level consensus may camouflage the real differences among countries. For example, underneath the consensus on the value creation principle in the BEPS Project, OECD countries may wish to clarify and update the guidance on the application of the arm's length principle, but non-OECD countries which regard transfer pricing as the most important aspect of the project, ${ }^{85}$ may wish to go beyond the arm's length principle and achieve a more "fair" allocation of the tax base. In terms of implementing the BEPS measures, EU countries have taken a different approach from the US. BRICS have embraced BEPS project and used it as an opportunity to embark on a new era of global tax governance.

A more value-based approach, as opposed to a more rule-based approach, may be more realistic in the near future. The BEPS Project signaled that the process of reform has became more topdown because G20, with its political clout, directed the BEPS Project and relied on the OECD for technical support. This is in contrast to the previous reform efforts led by the OECD, which follow a bottom-up approach and was driven by technocrats who were specialized in fiscal policy and 
taxation. ${ }^{86}$ The BEPS project may also signal the end of American "constructive unilateralism" in setting international tax standard. ${ }^{87}$ In the past, American "tax architects", such as Seligman, Thomas and Carroll, were instrumental in shaping the international tax system ${ }^{88}$ and American tax policies have influenced other OECD countries and the work of OECD. In the future, EU may take a different pathway, as is shown in the area of digital taxation. China and India have started to challenge the existing norms.

The value creation principle may be broadly accepted as “fair”. The notion of "fairness" played an important role in the BEPS Project. ${ }^{89}$ In launching the project, G20 Leaders declared that “cross-border tax evasion and avoidance undermine our public finances and our people's trust in the fairness of the tax system." 90 The notion of fairness may be the conceptual basis of the value creation principle. ${ }^{91}$ For example, BRICS countries supported the value creation principle while stressing "the necessity of deepening international tax cooperation to build a fair and modern international tax system and boost the world’s economic growth” (emphasis added). ${ }^{92}$ BRICS countries also vowed to implement the "G20 tax agenda" and acknowledged their "common understanding that profits should be taxed in those jurisdictions where the activities generating those profits are performed." 93 The EU Commission has also noted that the value creation principle "is essential for a fair and effective taxation in the single market". 94 "The principle's popular appeal perhaps can also be understood on the grounds that it appears to follow an intuitive understanding of fairness, along the lines of the benefits principle that contributions to the cost of publicly-provided goods and services should be allocated based on the benefits derived from them." 95

Many developing countries have joined the Inclusive Framework, thereby embracing the value creation principle. Some of these countries may suffer more harms from the BEPS than developed countries for several reasons. First, BEPS practices erode the corporate tax base of the source country and corporate tax generates a greater share of total tax revenues in developing countries, and ss such, the adverse impact of revenue loss is more severe. ${ }^{96}$ Second, developing countries' tax laws are often less sophisticated and more susceptible to tax planning and the tax authorities lack resources to enforce complex rules, such as transfer pricing rules. ${ }^{97}$ An effective source-based taxation, which was intended, arguably, by the value creation principle, could permit developing countries to have a "fair" share of the MNE's profit. ${ }^{98}$ It is also possible that as a result of the 
BEPS Project, the effective increase in tax burdens will be greater in developed countries than in developing countries, which will make doing business in developing countries more attractive. ${ }^{99}$ Also, the value creation principle's emphasis on actual economic activities may lead some MNEs to relocate their value-creation activities physically to those developing countries that offer tax incentives. ${ }^{100}$ Therefore, even though the BEPS Project was launched by the world most powerful countries to counter tax planning by powerful MNEs and was not designed to help developing countries per se, the project has been accepted by developing countries. The value creation principle may have contributed to their acceptance.

\section{PROPOSING A GLOBAL PROFIT SPLIT APPROACH}

\subsection{Tackling the Issue of Residual Profit}

Building on the momentum of the BEPS Project and the value creation principle, we propose to allocate MNEs’ profits according to a global profit split approach ${ }^{101}$ that is paired with a minimum standard for tax competition. We think this approach is politically feasible, technically viable, and conceptually aligned with the value creation principle.

At the heart of the challenges in allocating profits of MNEs is income from intangibles, which can be conceptually understood as anything that is not tangible and has value. ${ }^{102}$ The existing transactional residual profit split method separates "routine profit" derived from tangible assets and business functions and risks and "residual profit” attributable to intangibles. BEPS Action 810 Report states that:

For intangibles, the guidance clarifies that legal ownership alone does not necessarily generate a right to all (or indeed any) of the return that is generated by the exploitation of the intangible. The group companies performing important functions, controlling economically significant risks and contributing assets, as determined through the accurate delineation of the actual transaction, will be entitled to an appropriate return reflecting the value of their contributions. Specific guidance will ensure that the analysis is not weakened by information asymmetries between the tax administration and the taxpayer in relation to hard-to-value intangibles, or by using special contractual relationships, such as a cost contribution arrangement. ${ }^{103}$

Because the BEPS Project aimed to revise (not redesign) the transfer pricing methods to align profit for tax purposes with value creation, it suffers the flaws that plague the existing system. One flaw is the adherence to the separate entity principle (treating each member of an MNE group as a separate accounting unit), even though, in effect, the project has attempted to downplay the fiscal 
impact of legal fictions. ${ }^{104}$ Another flaw is the transactional, comparability approach that is based on the facts and circumstances of each case. Even with the enhanced data and information reporting by MNEs, in addition to the practical complexity, conceptually, this approach does not treat the MNE's global business as a unitary business. Instead, it continues to allocate profits between two parties to the transaction. Further, there is no or inadequate allocation to sales or market as the method is supply-sided. The reform proposals canvassed below seek to address this core problem.

\subsection{The Global Profit Split Proposal}

The proposed global profit split or GPS approach modifies and extends the newly revised profit split method to the global profits of MNE groups. It would allocate global profits to the involved countries (where an MNE has economic and value-creation activities) in a two-step process: (1) Routine profits would be allocated according to value-creation activities and functions (in production countries) in a manner similar to the revised transfer pricing guidance; and (2) Residual profits would be allocated according to a formula consisted of tangible assets, payroll/workforce and sales. Once profit has been allocated to a jurisdiction, it is up to that jurisdiction to decide the rate of tax, including zero rate. This is consistent with BEPS Action 5 as the profits subject to the preferential taxation has substantial nexus to that jurisdiction.

The success of the proposed approach will depend on a high-level consensus on the rules for determining global profits of an MNE group, the measurement and weight of apportionment factors, and a mechanism for resolving tax disputes. Compared to the alternative international tax reform proposals (see below), the GPS approach has some advantages.

\subsection{Alternative Proposals}

\subsubsection{Destination-based Methods}

A destination-based corporate tax ${ }^{105}$ would treat MNEs as unitary businesses rather than a constellation of separate legal entities. ${ }^{106}$ It would allocate residual profits based on where they sell their goods and services, that is, on a destination basis as opposed to the current origin basis (where activities and value creation take place). Propnents suggest that it is the future of the transfer pricing regime and corporate tax in general. ${ }^{107}$ The location of consumers is less mobile 
than the location of property, employees, other elements of value creation. Three specific proposals are canvassed below: a sales-based formulary apportionment, residual profit allocation on a production line basis and residual profit allocation to marketing intangibles.

\subsubsection{Sales-based formulary apportionment}

A formulary apportionment method ${ }^{108}$ would determine a MNE's profits for US tax purposes based on a fraction of the MNE's worldwide income. The fraction would be the sum of (a) a fixed return (suggested to be 7.5\%) on the MNE's expenses in the United States (as a measurement of real economic activities) and (b) the share of its worldwide sales that occur in the United States.

The single factor formulary apportionment based on sales is similar to the current method used by U.S. states in allocating national income across states. ${ }^{109}$ U.S. states have traditionally used a threefactor formula (property, payroll and sales), but moved to the sole sales factor in order to attract corporate investment in assets and jobs and sales is less mobile compared to assets and payroll.

According to the proponent, one of the advantages of this method is to "eliminate the tax incentive to shift income through legal and accounting devices, such as licenses of patents and other intangible property, to subsidiaries in zero-or low-tax countries" as "such shifting incentives often entail the movement of employees and plants." 110 Among the downsides of this method are its arbitrariness (e.g., fixing the rate of return for routine profits and using sales as the allocation key) and implementation challenges (such as defining the worldwide income, location of sales, and interactions between countries with different tax systems).

\subsubsection{Residual profit allocation on a product line basis}

Similar to the sales-based formulary apportionment method, this method assigns a normal rate of return to productive functions and allocate residual profit to the location of sales. But, proponents of this method attempt to keep this method in the existing arm's length transfer pricing regime by avoiding a formulary apportionment method. Instead, the proposed method deems the country in which sales take place to be an "entrepreneurial affiliate" with respect to local market sales and ascribes all non-routine profits to that deemed affiliate. ${ }^{111}$ In other words, other entrepreneurial functions, such as manufacturing, $R \& D$, services, and marketing receive routine profits only. In other words, instead of allocating residual profit to the affiliate that is the owner or performs 
DEMPE [development, enhancement, maintenance, protection, and exploitation of intangibles] functions, the residual profit is allocated to affiliates in the market jurisdictions.

Further, this proposed method requires a product line and country by country determination: gross revenues would be computed by country and by product using some concept of place of supply or destination and global costs would be measured at a product line level and then either traced or apportioned to revenues from specific countries. Because economic activities and value creation activities are rewarded with routine profits, this method reduces the uncertainty by attributing residual profit to the market jurisdiction using methods that are familiar under the existing transfer pricing regime.

\subsubsection{Residual profit allocation to marketing intangibles}

This method can be viewed as a derivative of the above destination-based residual profit allocation method. It goes one step further by singling out marketing intangibles. It would assign residual profits to the market jurisdiction to the extent that they are derived from marketing intangibles and leave residual profit from other intangibles to be assigned according to general transfer pricing principles. ${ }^{112}$

\subsubsection{Alternative minimum tax on global profits}

Without changing the existing paradigm of taxing MNEs on the basis of residence and source of income, proposals of alternative minimum tax aim at ensuring that MNEs’ profits are taxed at a minimal level. Earlier proposals by American scholars ${ }^{113}$ and the Obama Administration in the 2016 draft budget ${ }^{114}$ sought to strengthen residence-based taxation of U.S. based MNEs on a worldwide basis by eliminating deferral of US tax. The basic thinking is similar to that behind the controlled foreign corporation (CFC) rules in respect of foreign passive income. The 2017 US Tax Reform extended the CFC regime to foreign income from intangibles under the GILTI (global intangible low-taxed income) rules. ${ }^{115}$ Both the US CFC rules and GILTI rules ensure the targeted foreign income is taxed, at a minimum, at the US rate (which is half of the standard corporate tax rate for GILTI). ${ }^{116}$ CFC rules and GILTI rules are outbound rules as they target income derived from foreign investment and activities. 
The 2017 US Tax Reform also introduced an inbound minimum tax in the form of BEAT (base erosion anti-abuse tax). ${ }^{117}$ Recently, scholars suggest introducing a minimum effective tax for MNEs by pairing the inbound and outbound minimum taxes (i.e. BEAT plus CFC and GILTI) ${ }^{118}$ or introducing a global general anti-avoidance rule mandating a minimum global tax rate. ${ }^{119}$

The minimum tax approach has the advantage of building on the momentum of the BEPS Project in tackling the problem of stateless income. It requires countries to agree to the minimum effective tax rate and foregoing the use of tax incentives to attract substantive foreign investment. The latter requirement may be perceived as encroaching tax sovereignty in that their tax incentive policies would be rendered ineffective. To implement the proposal, countries would need to have a benchmark corporate tax system and use the minimum tax as an alternative system. An advantage of the proposal is that the existing international tax rules would continue and the minimum tax would not replace it, but only backstop it.

\subsubsection{Reversing the residence-source paradigm}

Under the current international tax paradigm, passive income is taxed primarily in the residence country and active income is taxed primarily in the source country. "Most of the current issues can be solved by taxing passive income primarily at source and active income primarily at residence.” ${ }^{120}$ This proposal seeks to tackle both the corporate tax avoidance issue and personal tax evasion problems. The assumption is that individuals earning passive income reside in a small number of high-income countries: the US, EU countries and Japan. If the source country imposes withholding tax on passive income, it would render the channeling of such income through intermediaries in tax havens meaningless (for tax purposes). There is no need for residence countries to get cooperation from tax haven jurisdictions.

As to active income, it should be taxed in the residence country. According to the proponents of this method, since 90\% of large MNEs are headquartered (resident) in G20 countries, if these countries tax their MNEs' global profit on a current basis (which is opposite to the current territorial system), it would render tax planning practices to erode source countries' tax ineffective. This proposal is like the minimum tax proposal in that all business profits are subject to tax under a CFC-like regime. In other words, CFC rules would be extended to global profits of MNEs headquartered in G20 countries. 
Proponents of the reverse paradigm approach did not spell out the details on the implementation. A great deal of faith was placed on the U.S. "constructive unilateralism”, ${ }^{121}$ that is the United States leads and other countries would follow. They acknowledge:

It is impossible to predict what will happen, but the history [in the US to deal with deferral] suggests that there is a good chance that other G20 countries will follow us if we abolish deferral at a lower rate. If that happens, all the usual objections to worldwide taxation (competitiveness, inversions, and the various neutralities) lose their force. We do not think there is a significant risk involved in this move, and the potential upside is quite large. ${ }^{122}$

\subsubsection{The CCCTB - Multi-factor Formulary apportionment}

The CCCTB (common consolidated corporate tax base) proposed by the European Commission in $2016^{123}$ is a multi-factor formulary apportionment regime. Under the CCCTB, the profit of all entities being part of corporate group above a specified threshold (750 million Euros) turnover would be computed under harmonized rules and the consolidated profits (and losses) would be apportioned to each involved country according to a formula composed of fixed assets, payroll/workforce and sales. ${ }^{124}$ The EU also proposed that the CCCTB would apply to taxing digital companies that ${ }^{125}$ have a "digital presence" in a EU member scountry. ${ }^{126}$

Unlike the destination-based formulary apportionment, the CCCTB applies to the entire group profits, not just residual profits. By default, income derived from intangibles would be allocated to countries based on the three factor, thereby favouring countries where productive activities and sales take place, not where high-value intangibles are created. The required harmonization of rules on computing profits and agreement on the measurement of the allocation factors have made it difficult for the adoption of the CCCTB in the EU.

\subsection{A Global Profit Split Approach for the $21^{\text {st }}$ Century}

Compared to the existing tax paradigm for taxing MNEs and the altnerative proposals, we suggest that the proposed global profit split or GPS approach has some advantages. It is more aligned with the value creation principle; it is evolutionary in nature; and has a greater chance of implementation. 


\subsubsection{Consistency with the value creation principle}

In spite of the drawbacks canvassed in Part 2 above, the value creation principle could be viewed as the first global tax principle. The proposed GPS approach is consistent with this principle. Under this approach, the global business profit of MNEs is treated as the total taxable income (or value) and is allocated to the involved jurisdictions where value is created. As such, no profit would be allocated to pure intermediary jurisdictions. It differs from the existing transfer pricing regime that fragmentizes the global profit into bits that can be measured by national tax laws, leaving opportunities for some of the bits be allocated to intermediary jurisdictions.

Moreover, the proposed GPS approach is substance-based. Intra-group contractual arrangements and the use of legal fictions are not relevant, and only value-creating activities and functions are taken into account. It recognizes value creation activities taken place in production countries, market countries as well as intangible-creation (or DEMPE) countries. As such, profit arising from global value chains is captured and allocated to the countries involved in the chains. As compared to the existing system which allows MNEs' residual profit to low-tax intermediary jurisdictions ${ }^{127}$ the proposed GPS approach as the advantage of eliminating the attractiveness of channeling profits to such jurisdictions. ${ }^{128}$

It can be argued that the proposed GPS approach is more aligned with the business realities. The business of MNEs are globally integrated, and the whole is greater than the sum of its parts. The business is integrated when interdependent basic operations are carried on to a substantial extent in different jurisdictions by the branches or subsidiaries that constitute the controlled enterprise. The GPS approach recognizes this changed economic reality and can fairly allocate the residual profit of an MNE to all participants in an integrated business. It is thus superior to existing methods, which either cannot account for residual profit (in the case of transactional methods) or cannot fairly allocate it. ${ }^{129}$

Compared to the destination based proposals, the GPS approach recognizes value created in both production jurisdictions, DEMPE jurisdictions and market jurisdictions and is thus more aligned with the value creation principle. It is similar to the sales-based formulary apportionment proposal and the CССТВ approach by using formulary method to allocate MNEs' global profit. It differs from the global minimum tax proposal by permitting countries to continue to operate preferential 
tax regimes as long as they are constrained to the profits that are allocated to them. In other words, the proposed global profit split method,

\subsubsection{Evolutionary nature}

The GPS approach represents a more "natural” evolution from the existing transactional profit split method and the existing paradigm of taxing MNEs. As a "globalized” profit split method, the GPS continues the tradition of separating routine profits and residual profits. It can be viewed as a logical addition to the toolbox used to give meaning to the arm's length principle. ${ }^{130}$ In other words, GPS is not a radical departure from the arm's-length principle, but rather a natural development in its evolution. The GPS approach can also be viewed as a logical global expansion of the traditional formulary apportionment methods used by sub-national governments in Canada and the United States or the globalization of the EU CCCTB mechanism. ${ }^{131}$

The GPS is not a departure from the theoretical underpinnings of the existing international tax system, that is the economic allegiance theory, tax benefit theory or tax neutrality theory. It strengthens tax sovereignty by permitting countries to choose their tax rates (including zero rate) for profit allocated to them. To the extent the GPS approach renders corporate residence redundant as a basis for taxing MNEs' income, the GPS can be viewed as protecting the tax base of countries where value is created and residence status per se produces no value. Therefore, the GPS represents incremental changes to the existing system which reflects the aphorism natura non facit saltumnature makes no sudden leaps. ${ }^{132}$

It is true that the OECD has insisted that a "global formulary apportionment" using predetermined formulae is inconsistent with the arm's length principle. ${ }^{133}$ However, the BEPS Project has signaled greater use of profit split analyses. The OECD Revised Guidance on the Application of the Transactional Profit Split Method - BEPS Action 10 (July 2018 ), while retaining the rhetoric

of transactional approach, states that profit split may be the most appropriate method in the presence of one or more of the following indicators: each party makes unique and valuable contributions; the business operations are highly integrated; or the parties share the assumption of economically significant risks, or separately assume closely-related risks. The profit splitting factors assets, capital, time spent or headcounts, data on which can be found in the CbCR filings. 


\subsubsection{Technical feasibility}

The GPS approach is technically feasible owing to the practical experience in applying profit split method, national experience with formulary apportionment, and recent reform initiatives. In practice, profit split methods are "routinely accepted by taxpayers and tax authorities alike", and "have become the standard method" in certain industries, such as global trading. ${ }^{134}$ The increased integration of global business operations "makes the use of profit splits unavoidable."135

More importantly, OECD countries are taking action that defies the OECD's rhetorical insistence that formulary apportionment is against the arm's length principle. EU countries follow the arm's length principle in their domestic laws and tax treaties but may soon adopt the CCCTB regime. Even if the CССТВ were not adopted in the near future, it has not been rejected on the ground of violating the arm's length principle. The enhanced global value chain analysis following the BEPS Project is viewed as bridging the СССТВ and the arm's length principle. ${ }^{136}$

Through the GILTI, FDII and BEAT rules, the United States effectively adopted a " $50-50$ global profit-split mechanisms in the 2017 Tax Reform: ${ }^{137}$

On the one hand, these provisions are not specifically framed in terms of exceptions to the arm's length principle or the definition of "intangibles" of the OECD Guidelines, embodied in Section 482 of the US Internal Revenue Code. On the other hand, they certainly reflect a US Congressional conclusion that the existing transfer pricing and related principles of US law are not, on their own, sufficient to protect the US tax base from aggressive effective tax rate planning strategies ... of MNEs. These mechanisms could be viewed as introducing an underlying "intangible" in the form of a price to be paid for access to the US marketplace. ${ }^{138}$

Non-OECD countries have been less dogmatic about the arm's length principle in general. For example, China has permitted the use of any "reasonable method" in determining the appropriate amount of profit of an MNE for Chinese tax purposes, including a share of global profit. ${ }^{139}$ China, India and Brazil declared in the UN Manual on Transfer Pricing that they do not fully accept the OECD approaches to transfer pricing ${ }^{140}$ They are determined "to shake up the international tax system to assert very strongly the importance of the corporate income tax as a source tax and not to give up on it” and the focus has mainly been on transfer pricing. ${ }^{141}$ These countries and developing countries may find the proposed GPS easier to apply and result in a fair outcome for them. 
The CbCR, Multilateral Instrument and dispute resolution mechanisms introduced by the BEPS Project are expected to help countries implement the GPS approach. Even if developing countries lack capacity to administer the formulary apportionment regime, they would not lose any existing tax base because of routine profits would be allocated to production activities.

\subsubsection{Political feasibility}

The strongest argument in favor of the GPS approach over the alternative proposals is the political feasibility. We can assume that the world has four types of countries in terms of value creation: production countries that produce goods and services, market countries where goods and services are sold; DEMPE countries where intangibles are created, and tax haven countries that are intermediary jurisdictions. The proposed GPS approach has a better chance of being perceived to be fair by all countries except tax havens. Production countries would have a tax base reflecting a routine return on productive activities as well as a share of residual profit attributable to productive factors (assets and people). DEMPE countries would receive a share of global profit based on assets and payroll. Market countries would have a tax base reflecting a share of residual profit based on sales, which is better than the existing system under which they are not entitled to sharing the residual profit. Tax haven jurisdictions have been the target of harmful tax practices initiatives and the BEPS Project and will not receive any share of global profit unless value-creation activities occur there. Non-tax haven countries would be expected to continue to have a united front in preventing profit shifting to tax havens.

In the foreseeable future, tax policies will continue to reflect the fiscal choices of each sovereign state. The proposed GPS approach respects tax sovereignty by allowing countries to continue to decide if they want to engage in tax competition. Developing countries that prefer to use tax incentives to attract direct foreign investment would likely support such approach. Capital exporting countries can continue to use anti-abuse regimes to ensure that they can tax their share of the global profit (as determined under the GPS).

More importantly, perhaps, the GPS approach can lead to a more equitable outcome for developing countries which are production countries and/or market countries, but may have limited resources to asses MNEs. By allocating global profits according to a formula consisted of tangible assets, payroll/workforce and sales, the GPS approach can help reduce the erosion of source-based 
taxation in developing countries. It might be possible that a developing country's share is established under the GPS approach without involving much administrative resources of the developing country. The GPS approach would be simpler than the existing transfer pricing regime. In summary, the proposed GPS approach enjoys several advantages over the existing system for allocating international income. The GPS would be more equitable in allocating income among jurisdictions and be more consistent with both economic theory and the economic reality of how MNEs conduct their business. It could also help reduce tax incentives for shifting profit to tax havens. In terms of the overall structure of the international tax system, the GPS could simplify the system by reducing the need for other anti-avoidance rules that were designed to deal with problems unresolved by the transfer-pricing approach.

1 See e.g. Hugh Ault, Wolfgang Schon and Stephen Shay, "Base Erosion and Profit Shifting: A Roadmap for Reform,” Bulletin for International Taxation (June/July 2014) 275; Reuven Avi-Yonah and Haiyan Xu, "Evaluating BEPS: A Reconsideration of the Benefits Principle and Proposal for UN Oversight” (2016) vol. 6, issue. 2 Harvard Business Law Review 185-238 [hereinafter “Avi-Yonah and Xu - Evaluating BEPS”]; Charlie Beller, “GILTI - 'Made in America' for European Tax: Unilateral Measures, Excess Profits \& the International Tax Competition Game” (2019) Virginia Tax Review (Forthcoming); Yariv Brauner, "What the BEPS” (2014) vol.16, no. 2, Florida Tax Review 55-115; Allison Christians, "BEPS and the New International Tax Order" (2017) 6 BYU Law Review _; Allison Christians and Stephen Shay, "General Report" in Assessing BEPS: Origins, Standards and Responses (IFA Cahiers vol. 102A, IBFD 2017); Kimberly A. Clausing, "Profit Shifting Before and After the Tax Cuts and Jobs Act” (2018), available at SSRN: https://ssrn.com/abstract=3274827; Michael P. Devereux, and Vella, John, "Value Creation As the Fundamental Principle of the International Corporate Tax System”, European Tax Policy Forum Policy Paper (July 31, 2018), available at SSRN: https://ssrn.com/abstract=3275759, at 1 [hereinafter "Devereux and Vella (2018)"]; Michael C. Durst, "Taxing Multinational Business in Lower-Income Countries: A Problem of Economics, Politics and Ethical Norms ”,(2018) Volume 89, No.8, Tax Notes International; Itai Grinberg, "International Taxation in an Era of Digital Disruption: Analyzing the Current Debate" (October 29,2018), Available at SSRN: https://papers.ssrn.com/sol3/papers.cfm?abstract_id=3275737 (hereinafter "Grinberg - Digital Disruption”); Mindy Herzfeld, “Coordination or Competition? A BEPS Score Card” (September 26, 2016) Tax Notes International, 1093-5 (hereinafter "Herzfeld - Score Card”); --, "What's So Bad About BEPS” (May 23, 2016) Tax Notes International, 723 (hereinafter as "Herzfeld - About BEPS"); -- "Why BEPS Is Just the Beginning" (September 21, 2015), Tax Anlaysis, DOC 2015-20840 (hereinafter as "Herzfeld - BEPS Beginning”); Jinyan Li "China and BEPS: From Norm-Taker to Norm-Shaker" (2015) vol. 69, no. 6/7 Bulletin for International Taxation _; Pasquale Pistone and Yariv Brauner eds, BRICS and the Emergence of International Tax Coordination (IBFD, 2015); Sam Sim and Mei-June Soo eds, Asian Voices: BEPS and Beyond (2017, Online Books IBFD). Also, the BEPS project received coverage in mainstream media and social media owing to its political and social significance. See for example, David Jolly, "OECD Calls for Coordinated Fight Against Corporate Tax Avoidance”, New York Times, September 16, 2014; Allan Lanthier, “Tax avoidance is a multilateral question that needs unilateral answers", Globe and Mail, January 19, 2016 and Itai Grinberg and Joost Pauwelyn, "The Emergence of a New International Tax Regime: The OECD's Package on Base Erosion and Profit Shifting (BEPS)” (2015) vol. 19, issue 24, American Society of International Law Insight. 
2 OECD/G20 Base Erosion and Profit Shifting Project (BEPS Project) (http://www.oecd.org/tax/beps/), Information Brief- 2015 Final Report.

3 Liao Tizhong, "Participating In-depth in International Cooperation of Tax Administration and Continuing to Build Up An Upgraded Version of International Taxation” [Shendu canyu quanqiu shuishou hezuo, chixu dazao guoji shuishou shengjiban] (2016), 5 International Taxation in China 67 (in Chinese).

4 Reuven Avi-Yonah, “A Perspective of Supra-Nationality in Tax Law” in Pistone and Brauner, supra note 1, at 33.

${ }^{5}$ Reuven Avi-Yonah and Haiyan Xu, China and the Future of the International Tax Regime, available at SSRN: https://ssrn.com/abstract=3056796 [hereinafter “Avi-Yonah and Xu (2017)”].

6 Richard Vann, “Current Trends in Balancing Residence and Source Taxation” in Pistone and Brauner, supra note 1 , at 367.

7 Grinberg and Joost, supra note 1.

${ }^{8}$ OECD, BEPS Project Explanatory Statement: 2015 Final Reports, supra note 2, at para.8.

9 The BEPS Project was ambitious in several respects. First, this is the first attempt to revise the existing rules on such scale since the inception of the international tax system in the 1920s to 1940s. Second, the timeline for completing the project was ambitious. Previous rounds of changes to selected international tax rules, such as treaty provisions and transfer pricing guidance, tend to have more time, involving fewer players. Third, the process is under unprecedent political and public scrutiny, owing to the circumstances that give rise to the Project. Previous changes tend to be the result of more close-door discussions of technical tax people. Finally, the actual achievement of the goal is, by and large, beyond the control of the BEPS Project, owing to the "soft" law nature of the BEPS measures.

${ }^{10}$ See OECD Action Plan on Base Erosion and Profit Shifting, July 19, 2013 [hereinafter "BEPS Action Plan"]. G20 Leaders' Communiqué on September 6, 2013 endorsed the BEPS Action Plan, para.50 (unless otherwise specified, G20 documents are available at http://www.g20.utoronto.ca/).

${ }^{11}$ OECD, “About the Inclusive Framework on BEPS”.

${ }^{12}$ Research undertaken since 2013 confirms the potential magnitude of the BEPS problem, with estimates indicating annual losses of anywhere from 4-10\% of global corporate income tax (CIT) revenues, i.e. USD 100 to 240 billion annually. OECD, Measuring and Monitoring BEPS, Action 11 - 2015 Final Report.

${ }^{13}$ Ibid.

${ }^{14}$ Russia G20 Declaration 2013, para.50.

${ }^{15}$ Information Brief, supra note 2.

${ }^{16}$ R.S.C. 1985 (5 ${ }^{\text {th }}$ Supp.), c.1 (ITA).

${ }^{17}$ A company is resident in Canada if it is incorporated in Canada (ITA, s.250(4)) or has its central management and control in Canada.

${ }^{18}$ ITA, ss.2(3) and subsections 212(1)(2).

${ }^{19}$ OECD, Model Tax Convention on Income and on Capital (2017).

${ }^{20}$ United Nations Model Double Taxation Convention between Developed and Developing Countries (2017). 
${ }^{21}$ BEPS Action Plan, supra note 10.

22 OECD, BEPS Project Explanatory Statement: 2015 Final Reports, OECD/G20 Base Erosion and Profit Shifting Project, (2016: OECD Publishing, Paris) available at http://dx.doi.org/10.1787/9789264263437-en, para.6. The rewriting of tax rules was achieved by the BEPS Project through providing measures "which are designed to be implemented domestically and through treaty provisions in a coordinated manner, supported by targeted monitoring and strengthened transparency" with the goal of tackling "BEPS structures by comprehensively addressing their root causes rather than merely the symptoms.”

${ }^{23}$ Supra note 10.

24 These rules thus fall into two groups: (1) Domestic rules on hybrid mismatch arrangements in Action 2, controlled foreign company (CFC) rules in Action 3, interest deductions in Action 4, harmful tax practices and transparency in Action 5, transfer pricing rules in Actions 8, 9, 10 and 13 and mandatory disclosure in Action 12; (2) Treaty rules to prevent treaty abuse in Action 6, permanent establishment in Action 7, tax dispute resolution in Action 14, and a multilateral instrument for amending bilateral tax treaties. Tax rules for the digital economy in Action 1 remain unsettled and the final report is expected in 2020. For further, see OECD, Frequently Asked Questions, BEPS Project, supra note 2.

${ }^{25}$ Action 5 sets a minimum tax competition standard which is one substantial activity-based "nexus" approach for assessing preferential regimes and spontaneous exchange of tax information on tax competition in the form of preferential tax regimes(treatments). Action 6 has a minimum standard for treaty shopping to be included in the Multilateral Convention to Implement Tax Treaty Related Measures to Prevent BEPS (MLI). Action 13 has the country-by-country reporting (CbCR) standard. A minimum standard for resolving treaty-related disputes in Action 14. These minimum standards were agreed "to tackle issues in cases where action by some countries would have created negative spill overs (including adverse impacts of competitiveness) on other countries.” See OECD, Frequently Asked Questions, ibid. All G20/OECD members are committed to consistent implementation. Other countries participating in the Inclusive Framework must similarly commit to implementing these standards and agree to be peer reviewed and monitored.To facilitate the implementation of these standards, the BEPS Package contains templates or model legislation.

${ }^{26}$ Examples are the arm's length standard for transfer pricing in Actions 8-10 and standard for identifying harmful tax competition in Action 5.

27 There is an expectation that countries will converge over time through the implementation of the agreed common approaches, thus enabling further consideration of whether such measures should become minimum standards in the future.” David Bradbury, Achim Pross and Marlies de Ruiter, "Inside observations on the BEPS Project" (December 15, 2015) International Tax Review 1.

${ }^{28}$ Guidance based on best practices is contained in Reports on Action 3 (Controlled Foreign Company Rules) and Action 12 (Mandatory Disclosure Rules). This is the "lowest” level of measures in terms of "legal” hierarchy. In the case of CFC rules, the OECD has not done significant work in the past in the area. The Report on Action 3 only sets out recommendations in the form of building blocks in designing CFCs, not minimum standards or common approaches. These recommendations provide flexibility to countries in implementing CFC rules in a manner consistent with the policy objectives of the overall tax system and the international legal obligations of the country concerned. In the case of mandatory disclosure of aggressive tax planning schemes, The Report on Action 12 provides recommendations on design principles and key objectives of a mandatory disclosure regime for countries that do not have them. Countries "are free to choose whether or not to introduce mandatory disclosure regimes" (at 9).

${ }^{29}$ Because the digital economy raises fundamental questions about the adequacy of existing rules which were designed for an industrial era and a more physical world, rewriting of existing rules cannot address the "broader" tax policy issues. Developing consensus on new rules requires a great deal of time and efforts. The Report on Action 1 explains the tax challenges (in particular regarding nexus, data, and characterisation for income taxes) 
and provides options for consideration. An Interim Report was released in March 2018 and a final report is to be released in 2020.

${ }^{30}$ See BEPS Report on Action 2.

${ }^{31}$ OECD, Limiting Base Erosion Involving Interest Deductions and Other Financial Payments, Action 4 - 2015 Final Report, BEPS Project, supra note 2, at 11.

${ }^{32}$ OECD, Executive Summaries: 2015 Final Reports, BEPS Project, supra note 2, at 28.

33 The revised guidance also leans towards more reliance on transactional profit split method and mandates followup work on this method in circumstances such as the integrated global value chains. The revisions have now been included in OECD Transfer Pricing Guidelines for Multinational Enterprises and Tax Administrations 2017, OECD Publishing, Paris, https://doi.org/10.1787/tpg-2017-en.

${ }^{34}$ BEPS Action 15 Report, Developing a Multilateral Instrument to Modify Bilateral Tax Treaties, see BEPS Project, supra note 2 .

${ }^{35}$ OECD, “Signatories and Parties to MLI”, available at http://www.oecd.org/tax/treaties/beps-mli-signatories-andparties.pdf.

36 Turkey G20 Leaders Communique, 2015, para.15.

${ }^{37}$ Ibid.

${ }^{38}$ OECD, BEPS Project Explanatory Statement: 2015 Final Reports, OECD/G20 Base Erosion and Profit Shifting Project, (2016: OECD Publishing, Paris) available at http://dx.doi.org/10.1787/9789264263437-en, para.9.

${ }^{39}$ Ibid, at para.24.

${ }^{40}$ In 2014, the OECD established a single, common global requirement - the Common Reporting Standard (CRS) for financial institutions to share financial account information with tax authorities and then exchange that information with their foreign counterparts on an agreed, annual basis. The CRS has made available to tax authorities information on offshore transfers and accounts which was previously unknown and unknowable. According to the OECD, by the end of 2018, over 100 jurisdictions had begun automatic exchanges, see OECD Automatic Exchange Portal, available at http://www.oecd.org/tax/automatic-exchange/commitment-andmonitoring-process/.

41 Turkey G20 Leaders’ Communique, 2015, para.15. Countries that participate in the Inclusive Framework must develop a monitoring process for the four minimum standards as well as review mechanisms for other BEPS Measures. The mandate of the Inclusive Framework includes providing support to member countries and develop further guidance and practical toolkits that target the BEPS priority issues identified by low capacity developing countries

${ }^{42}$ Mindy Herzfeld, “Political Reality Catches Up with BEPS” (May 25, 2015) Tax Notes International 387.

43 OECD, Harmful Tax Competition: An Emerging Global Issue (1998) available at https://www.oecdilibrary.org/taxation/harmful-tax-competition_9789264162945-en.

${ }^{44}$ For example, coordination in taxing e-commerce took place through the OECD, including the 1998 Ottawa taxation framework conditions - Principles. See an overview in OECD BEPS Action 1 Final Report (2015), Annex A. According to the official website (http://www.oecd.org/tax/transparency/), the Global Forum currently (December 2018) has 154 members. It is "the premier international body for ensuring the implementation of the internationally agreed standards of transparency and exchange of information in the tax area”. It also has “an in- 
depth peer review process” to monitor its members' implementation of the standard of transparency and exchange of information they have committed to implement.

${ }^{45}$ The residence-source paradigm favours residence countries and the existing transfer pricing rules allocate only routine profits to developing countries (for labour and tangible assets and production activities) and residual profits to developed countries (intangibles, apital, risk and group synergy). Reducing the bias inevitably results in reallocation of taxing rights between developing countries and developed countries, which involves geopolitics. See Allison Christians, "Taxing According to Value Creation" (June 18, 2018) Tax Notes International, 1079-83; Christians and van Apeldoorn, "The OECD Inclusive Framework" (April/May 2018) Bulletin for International Taxation, 226-33; and Miranda Stewart, "Redistribution between rich and poor countries" (2018) vol. 72, no. 4/5 Bulletin of International Taxation, 297-309, at 306.

${ }^{46}$ For further discussion, see Tatiana Falcao and Bob Michel, "Scope and Interpretation of Article 12A: Assessing the Impact of the New Fees for Technical Services Article” (2018) British Tax Review 422-440

${ }^{47}$ Until February 2018, all preferential patent box regimes are consistent with the nexus approach of BEPS Action 5. The regimes that did not meet BEPS Action 5 nexus requirement amended their legislation or abolished the regimes. Some countries, like Portugal, whose patent box regimes were seen as non-harmful still changed the design to make it more compliment with the nexus requirements.

${ }^{48}$ OECD, “OECD releases decisions on 11 preferential regimes of BEPS Inclusive Framework Members” OECD (May 17, 2018).

${ }^{49}$ Christians and Shay, supra note 1, at 53-4.

${ }^{50}$ Michael Lennard, "Base Erosion and Profit Shifting and Developing Country Tax Administrations” (2016) 44 Intertax 10, at 745.

${ }^{51}$ Hugh J. Ault and Brian J. Arnold, "Protecting the tax base of developing countries: an overview” in Alexander Trepelkov, Harry Tonino and Dominika Halka eds., United Nations Handbook on Selected Issues in Protecting the Tax Base of Developing Countries (2nd Edition, United Nations, 2017).

52 Irma Johanna Mosquera Valderrama, “Output Legitimacy Deficits and the Inclusive Framework of the OECD/G20 Base Erosion and Profit Shifting Initiative” (March 2018) Bulletin for International Taxation 160; Christians and Shay, supra note 1.

${ }^{53}$ For UK diverted profit tax, see HM Revenue \& Customs, Diverted Profits Tax: Guidance (Nov. 30, 2015). For similar rule in Australia, known as "multinational anti-avoidance law(MAAL)", see Parliament of the Commonwealth of Australia, House of Representative, Tax Laws Amendment (Combating Multinational Tax Avoidance) Bill 2015: Explanatory Memorandum, 23-52 .

${ }^{54}$ Grinberg - International Taxation in the Era of Digital Dirsruption, supra note 1.

55 OECD Interim Report on Digital Economy (2018); UK HM Treasury, “Corporate tax and the digital economy: position paper update” (March, 2018) Tax Notes International; EU Commission, Impact Assessment Accompanying the document Proposal for a Council Directive laying down rules relating to the corporate taxation of a significant digital presence and Proposal for a Council Directive on the common system of a digital services tax on revenues resulting from the provision of certain digital services, SWD (2018) 81 Final, available at https://ec.europa.eu/taxation_customs/sites/taxation/files/fair_taxation_digital_economy_ia_21032018.pdf.

${ }^{56}$ Sim and Soo, supra note 1.

${ }^{57}$ OECD, Tax Challenges Arising from Digitalisation - Interim Report 2018: Inclusive Framework on BEPS, BEPS Project, supra note 2. 
${ }^{58}$ OECD, “Tax and Digitisation” (October 2018) available at https://www.oecd.org/tax/beps/tax-and-digitalisationpolicy-note.pdf. OECD, Standard for Automatic Exchange of Financial Account Information in Tax Matters, Second Edition, (Paris: OECD Publishing, 2017) available at https://doi.org/10.1787/9789264267992-en.

${ }^{59}$ Information Brief, supra note 2, at 3.

${ }^{60}$ See, for example, Allison Christians, "Taxing According to Value Creation” (June 18, 2018) Tax Notes International, 1079-83; Devereux and Vella (2018), supra note 1, at 1; Mindy Herzfeld, "The Case against BEPS: Lessons for Tax Coordination" (2017) vol. 21, no. 1 Florida Tax Review 1-59, at 42 [hereinafter "Herzfeld - The Case Against BEPS”]; Johanna Hey, “'Taxation where value is created' and the OECD/G20 Base Erosion and Profit Shifting initiative" (April/May 2018) Bulletin for International Taxation 203; S.C. Morse, "Value Creation: A Standard in Search of a Process" (2018) 72 Bulletin for International Taxation 196, at 204-5; Itai Grinberg, “User Participation in Value Creation” (2018) issue 4 British Tax Review 407-21; and Frans Vanistendael, “An Octogenarian on Value Creation” (June 18, 2018) vol. 90, no. 18 Tax Notes International 1385.

${ }^{61}$ Devereux and Vella (2018), at 1.

${ }^{62}$ See Jinyan Li and Arthur Crockfield, International Taxation in Canada, 4th ed (Toronto: LexisNexis, 2018), at 12; and Michael J. Graetz and Michael M. O’Hear, “The ‘Original Intent’ of U.S. International Taxation” (1997) vol. 46 Duke Law Journal 1021-109, at 1033.

${ }^{63}$ E.g. Li and Cockfield, ibid, at 7-10.

${ }^{64}$ UK HM Treasury, “Corporate tax and the digital economy: position paper update” (March, 2018) Tax Notes International.

${ }^{65}$ OECD, Transfer Pricing Documentation and Country-by-Country Reporting, Action 13 - 2015 Final Report (see BEPS Project, supra note 2) requires MNEs "to provide all relevant governments with needed information on their global allocation of income, economic activity and taxes paid among countries according to a common template" (at 23).

${ }^{66}$ Steef Huibregtse, Sonia Catalina, Munoz Rodriguez, Belisa Severini and Alejandro Delgado Perea , "Multinational Enterprises, Transfer Pricing and Value Chain Analysis in Latin America Following the OECD/G20 Base Erosion and Profit Shifting Initiative”, Bulletin for International Taxation (November 2018) 636.

${ }^{67}$ This understanding of value creation is criticized by Deveraux and Vella (2018), supra note 1; Itai Grinberg, "User Participation in Value Creation” (2018) issue 4, British Tax Review 407-21; and Grinberg -- Digital Disruption, supra note 1.

${ }^{68}$ Jinyan Li and Stephan Ji, "Location Specific Advantages: A Rising Disruptive Factor in Transfer Pricing” (May 1, 2017) 71(5) Bulletin for International Taxation 259, available at SSRN: https://ssrn.com/abstract=3164993.

${ }^{69}$ Mindy Herzfeld, "Splitting Profits with Communists” (August 10, 2015) Tax Notes International, 467-9; and Mindy Herzfeld, “GDP, Transfer Pricing and Value Created” (September 3, 2018) Tax Notes, 1362-6.

${ }^{70}$ For further discussion, see Herzfeld - The Case against BEPS, supra note 60, at 42-3; and Devereux and Vella, "Are we heading towards a corporate tax system fit for the 21st century?” (2014) Oxford Legal Studies Research Paper No. 88/2014, available at SSRN: https://ssrn.com/abstract=2532933

${ }^{71}$ Tax Annex to the Saint Petersburg G20 Leaders Declaration (2013) describes four fundamental aspects of the BEPS Project as: addressing the gaps between countries' tax systems; examining existing treaty rules, permanent establishment and transfer pricing to ensure that profits are taxed where economic activities occur and value is created; transparency; and 18-24 months time line for deliverables. 
72 OECD, Aligning Transfer Pricing Outcomes with Value Creation, Actions 8-10 - 2015 Final Reports, OECD/G20 Base Erosion and Profit Shifting Project (Paris: OECD Publishing, 2015), available at http://dx.doi.org/10.1787/9789264241244-en, at 9 [hereinafter “Actions 8-10 Report”].

${ }^{73}$ Hey, supra note 60, at 206.

${ }^{74}$ Ibid., at 207.

${ }^{75}$ This is reiterated in the Tax Annex to the Saint Petersburg G20 Leaders Declaration (2013).

${ }^{76}$ See, for example, Jinyan Li, International Taxation in China: A Contextualized Analysis (2016, IBFD); Li and Ji, supra note 68; United Nations, Practical Manual on Transfer Pricing for Developing Countries (New York: United Nations, 2017) [hereinafter "UN Manual on Transfer Pricing”], at 10.3.

${ }^{77} \mathrm{Li}$, ibid.

${ }^{78}$ Reuven Avi-Yonah, Kimberly A. Clausing and Michael C. Durst, “Allocating Business Profits for Tax Purposes: A Proposal to Adopt a Formulary Profit Split” (2009) vol. 9, no. 5 Florida Tax Review 497-553; Reuven AviYonah, "A Proposal for Unitary Taxation and Formulary Apportionment to Tax Multinational Enterprises" in Global Tax Governance p. 289 (P. Dietsch \& T. Rixen eds., ECPR press 2016); and Jinyan Li, "Global Profit Split: An Evolutionary Approach to International Income Allocation” (2002), 50:3 Canadian Tax Journal 823-83 [herein after "Li (2002)”].

${ }^{79}$ European Commission, "Proposal for a Council Directive of 25 October 2016 on a Common Corporate Tax Base, COM” (2016) EU Law IBFD [hereinafter: the "Proposed CCCTB Directive (2016)”].

${ }^{80}$ Actions 8-10 Report, supra note 72, at 11, 55 and 60.

${ }^{81}$ Devereux and Vella (2018), supra note 1. In addition to policymakers, some commentators share this view. See Richard Vann, "Policy Forum: The Policy Underpinnings of the BEPS Project-Preserving the International Corporate Income Tax?” (2014) 62:2 Canadian Tax Journal 433-41, at 41.

${ }^{82}$ Morse, supra note 60, at 196, notes that one key to the meaning of a standard is the process through which the standard is "rulified": what forum will make decisions on specific facts? Who can access the forum for decision? Will the decisions be transparent? One key to the meaning of a standard is the process through which the standard is "rulified".6 For instance: What forum will make decisions on specific facts? Who can access the forum for decision? Will the decisions be transparent?

${ }^{83}$ Hey, supra note 60 , at 205, noting that the notion of value creation can turn out to be "a new variant of the source principle".

${ }^{84}$ Pistone and Brauner, supra note 1.

${ }^{85}$ The Minister of Finance, China stated that for developing countries, including China, transfer pricing is a major BEPS aspect, resulting in base erosion and profit shifting: see Economic Observers News, September 11, 2016 (经济观察报) http://finance.sina.com.cn/roll/2016-09-11/doc-ifxvukhv8066966.shtml.

${ }^{86}$ Herzfeld - About BEPS, supra note 1; Buttner and Thiemann, "Breaking Regime Stability? The Politicization of Expertise in the OECD/G20 Process on BEPS and the Potential Transformation of International Taxation” (2017) Accounting, Economics, and Law: A Convivium, De Gruyter, 1-16; Herzfeld --The Case against BEPS, supra note 60 . 
${ }^{87}$ Reuven S. Avi-Yonah, “Constructive Unilateralism: US Leadership and International Taxation (June 25, 2015) University of Michigan Public Law Research Paper No. 463, available at

SSRN: https://ssrn.com/abstract=2622868; Mindy Herzfeld, "PEs and FTCs: Who Wins, Who Loses?” (April 27, 2015) Tax Notes International, 320-6; Graetz and O’Hear, supra note 62. Grinberg and Pauwelyn, supra note 1, observed: "In most other fields, non-cooperation by the United States would be fata. Not so in international tax, where the bargaining power of the U.S. is relatively weak and multilateral discussions without U.S. support can constrain U.S. national interests.

${ }^{88}$ Graetz and O’Hear, Ibid.

${ }^{89}$ The BEPS Project seems to have highlighted several aspects of fairness, including: (1) Inter-taxpayer fairness in the sense that some taxpayers (e.g., MNEs engaging in BEPS practices) do not pay their fair share of taxes; (2) Inter-nation fairness in the sense of establishing a "more effective, efficient and fair international tax system"; (3) Revising existing transfer pricing and devising rules for digital businesses and transparency and information sharing are presumably measures to ensure that the international tax base is shared fairly; (4) Fair tax competition among countries according to the minimum standards in Action 5; (5) Fairness in opportunity of participating in global tax governance. The BEPS Project emphasized that all countries are on an "equal footing" in participation in the work of the project and in implementing minimum standards through the Inclusive Framework. See G20 Leaders Communice, at para.6; BEPS Action Plan, at p.8 and p.25; Inclusive Framework, supra note 11. For comments on whether developing countries are actually participating on an equal footing, see Christians and van Apeldoorn, supra note 46; and Valderrama, supra note 52.

${ }^{90}$ G20 Leaders Communique, at para.6.

${ }^{91}$ Devereux and Vella (2018), supra note 1, at 6.

92 "The Fifth Meeting of BRICS Heads of Tax Authorities Successfully Concluded with Fruitful Outcomes" at https://www.brics2017.org/English/PhotoGallery/201708/t20170828_1813.html.

${ }^{93}$ Communiqué of BRICS Heads of Tax Authorities Meeting issued in Hangzhou on 27 July 2017, at http://idg.receita.fazenda.gov.br/noticias/ascom/2017/julho/receita-federal-participa-de-reuniao-dos-paisesbrics/communique-meeting-of-brics-heads-of-tax-authorites.pdf.

${ }^{94}$ EU Commission, Impact Assessment, at p. 5.

${ }^{95}$ Devereux and Vella (2018), supra note 1, at 6 (This paper finds linking the value creation principle to the benefits principle is problematic as profit is likely to be a poor proxy for the benefit received).

${ }^{96}$ Michael C. Durst, “Taxing Multinational Business in Lower-Income Countries” (2018) 89:8 Tax Notes International, 713-22; and L. Abramovsky, A. Klemm and D. Phillips, "Corporate Tax in Developing Countries: Current Trends and Design Issues” (2014) 35 Fiscal Studies 4, at 559-84. Developing countries also give away tax revenue in tax incentives. See Miranda Stewart, "Redistribution between rich and poor countries" (2018) vol. 72, no. 4/5 Bulletin of International Taxation, 297-309, at 306.

${ }^{97}$ UN Manual on Transfer Pricing, supra note 95. Many developing countries are also less capable of obtaining the necessary information to enforce tax collection. However, not all developing countries impose source-based taxation. Some do not even have a corporate tax, and may even be tax havens for MNEs.

${ }^{98}$ In regard to source-basis taxation of corporate income, Peggy Musgrave states: “This permits a country to share in the gains of foreign-owned factors of production operating within its borders; gains which are generated in cooperation with its own factors, whether they be natural resources, an education and/or low-cost work force, or the proximity of a market. The tax revenue so obtained may be thought of as a national return to the leasing of these complementary factors to non-resident investors or temporary workers, or, such taxation may be thought of in benefit terms, as a quid pro quo payment for cost-reducing, profit-enhancing services provided by the host 
country.” See P.B. Musgrave, “Sovereignty, Entitlement, and Cooperation in International Taxation” (2001) 26:4 Brooklyn Journal of International Law, 1335, at 1341-2.

${ }^{99}$ For further discussion, see Eric Zolt, “Tax Incentives in Develop ing Countries” in Alexander Trepelkov, Harry Tonino and Dominika Halka eds., United Nations Handbook on Selected Issues in Protecting the Tax Base of Developing Countries (2nd Edition, United Nations, 2017), 523 at 567-8.

${ }^{100}$ Devereux and Vella (2014), supra note 70, at 10. This paper argues that the result of such relation would cause economic distortions and reduce economic welfare as the relocation is tax-motivated.

${ }^{101} \mathrm{Li}$ (2002), supra note 77.

102 This is the approach in the US GILTI rules: see Grinberg - Digital Disruptions, supra note 1.

${ }^{103}$ BEPS Report on Action 8-10, at p.10.

${ }^{104}$ Scott J. Wilkie, "New Rules of Engagement? Corporate Personality and the Allocation of "International Income" and Taxing Rights" in Brian J. Arnold, ed. Tax Treaties after the BEPS Project: A Tribute to Jacques Sasseville (Canadian Tax Foundation 2018) 349.

${ }^{105}$ See, for example, Alan J. Auerbach, “Demystifying the Destination-Based Cash Flow Tax” (BPEA Conference, September 7-8, 2017), https://www.brookings.edu/wp-content/uploads/2017/09/5a_auerbach.pdf; Alan Auerbach, Michael Devereaux and Helen Simpson, “Taxing Corporate Income” NBER Working Paper 14494 (2008); Alan Auerbach, Michael Devereux, Michael Keen and John Vella. "International Tax Planning under the DestinationBased Cash Flow Tax” (2017) 70 (4) National Tax Journal (December), at 783; Devereaux and de la Feria, "Designing and Implementing a Destination-based Corporate Tax" WP 14/07 (May 2014); Joseph Andrus and Paul Oosterhuis, "Transfer Pricing After BEPS: Where Are We and Where Should We Be Going” (2017) volume 95, issue 3, Tax Magazine; and Devereux and Vella (2018), supra note 60; Michael Devereux and John Vella, "Implications of Digitalization for International Corporate Tax Reform" (2018) 46 Intertax 6-7, at 550-9 [hereinafter “Devereux and Vella - Implications of Digitization”].

106 The cash-flow aspect of the destination-based corporate tax proposal is beyond the scope of this paper. There has been strong criticism of the proposal. See, for example, Michael J. Graetz, "The Known Unknowns of the Business Tax Reforms Proposed in the House Republican Blueprint” (2017) vol. 8, no. 117, Columbia Journal of Tax Law, 2017; Reuven Avi-Yonah and Kimberly Clausing, "Problems with Destination-Based Corporate Taxes and the Ryan Blueprint” (2018) 8 Columbia Journal of Tax Law 229.

${ }^{107}$ For an excellent overview of these methods, see Grinberg - International Taxation in the Era of Digital Dirsruption, supra note 67.

${ }^{108}$ Reuven S. Avi-Yonah, Kimberly A. Clausing and Michael C. Durst, "Allocating Business Profits for Tax Purposes: A Proposal to Adopt a Formulary Profit Split” (2009) vol. 9, no. 5 Florida Tax Review 497-553.

${ }^{109}$ Ibid.

${ }^{110}$ Ibid., at 511.

${ }^{111}$ Andrus and Oosterhuis, super note 105, at 89. The conventional "entrepreneurial” model of transfer pricing assigns residual profit to the owner of intangibles and the BEPS Project modified that considering the global chain and contribution to the value of intangibles through performing DEMPE functions.

${ }^{112}$ See Grinberg - International Taxation in the Era of Digital Dirsruption, supra note 67; Paul Oosterhuis and Amanda Parsons, “Destination-Based Income Taxation: Neither Principled nor Practical” (2018) vol. 71, Tax Law Review 515-50. 
113 See, for example, Clifton Fleming Jr., Robert J. Peroni and Stephen E. Shay, "Territoriality in Search of Principles and Revenue: Camp and Enzi” (October 14, 2013) 72 Tax Notes International 155; and Harry Grubert and Rosanne Altshuler, "Fixing the System: An Analysis of Alternative Proposals for the Reform of International Tax” (2013) 66 (3) National Tax Journal 671-71 (a minimum tax on current profits derived by groups under the control of a US parent).

114 The budget included a 19\% minimum tax on foreign earnings, eliminate the deferral of U.S. tax on foreignearned income, and reduce the foreign tax credit to 85 percent of the value of foreign taxes paid. See https://www.govinfo.gov/content/pkg/BUDGET-2016-BUD/pdf/BUDGET-2016-BUD.pdf.

${ }^{115}$ For further discussion, see Kristina I. Novak, Mark P. Thomas and Cym H. Lowell, “Treatment of Intangibles under New US Tax Regime” (2018) July/August, International transfer Pricing Journal 259.

116 The CFC rules in Canada (Income Tax Act ss.91-95) and other countries function similarly.

${ }^{117}$ H. David Rosenbloom and Fadi Shaheen, “The BEAT and the Treaties,” Tax Notes International, Oct.1, 2018, p.53; Reuven Avi-Yonah and Bret Wells, “The BEAT and Treaty Overrides: A Brief Response to Rosenbloom and Shaheen” Tax Notes International, October 22, 2018, p.383; Daniel Shaviro, “The New Non-Territorial U.S. International Tax System, Part 1”, NYU Center for Law, Economics and Organization, July 2018.

${ }^{118}$ Grinberg - Digital Disruption, supra note 1.

${ }^{119}$ Rifat Azam, “Minimum Global Effective Corporate Tax Rate as General Anti-Avoidance Rule” (2017) 8:5 Columbia Journal of Tax Law 6.

${ }^{120}$ Avi-Yonah and Xu - Evaluating BEPS, supra note 1.

${ }^{121}$ Reuven S. Avi-Yonah, “Constructive Unilateralism: US Leadership and International Taxation (June 25, 2015) University of Michigan Public Law Research Paper No. 463, available at

SSRN: https://ssrn.com/abstract=2622868.

${ }^{122}$ Avi-Yonah and Xu - Evaluating BEPS, supra note 1, at 237.

123 Originally proposed in 2011 and recently in 2016, see https:/ec.europa.eu/taxation_customs/business/companytax/common-consolidated-corporate-tax-base-ccctb_en.

124 This proposal is similar to the method used in Canada to allocate corporate profits among provinces and the traditional method used by the states in the United States.

${ }^{125}$ EU, "Fair Taxation of the Digital Economy”, 21 March 2018, at https://ec.europa.eu/taxation_customs/business/company-tax/fair-taxation-digital-economy_en.

${ }^{126}$ A corporation would have a taxable 'digital presence' or a virtual permanent establishment in a Member State if it fulfils one of the following criteria: It exceeds a threshold of $€ 7$ million in annual revenues in a Member State; It has more than 100,000 users in a Member State in a taxable year; or over 3000 business contracts for digital services are created between the company and business users in a taxable year.

${ }^{127}$ Michael J. McIntyre, “Contracting Methodologies: A Systematic Presentation of the Differences Between an Arm's-Length/Source-Rule System and a Combined-Reporting/Formulary Apportionment System,” in Proceedings of the Eighty-Sixth Annual Conference on Taxation (Columbus, OH: National Tax Association, 1995), 226-35, at 232.

${ }^{128} \mathrm{Li}$ (2002), supra note 77, at 853. 
${ }^{129}$ Ibid., at 852 .

${ }^{130}$ Ibid., at 867.

${ }^{131}$ Ibid., at 866.

132 Joseph H. Guttentag, "Key Issues and Options in International Taxation: Taxation in an Interdependent World” (2001) vol. 55, no. 11 Bulletin for International Fiscal at 551.

133 See the OECD Transfer Pricing and Multinational Enterprises (1979) (pp.14-15); 1995 Transfer Pricing Guidelines (para.3.58-3.74) and 2017 OECD Transfer Pricing Guidelines pp.39-43. OECD cites the "most significant concern" with global formulary apportionment (which is not the same as the proposed approach in our paper) to be the difficulty of implementing the system in a manner that both protects against double taxation and ensures single taxation for the lack of consensus on the predetermined formula and on the composition of the MNE group in question (Transfer Pricing Guidelines 2017) (para.1.22).

134 Richard S. Collier \& Joseph L. Andrus, Transfer Pricing and the Arm's Length Principle after BEPS (Oxford: Oxford University Press, 2017)at 271.

135 Ibid.

136 See, for example, René Offermanns, Steef Huibregtse, Louan Verdoner and Jakub Michalak, "Bridging the CCCTB and the Arm's Length Principle - A Value Chain Analysis Approach” (November 2017) European Taxation, 466-80.

${ }^{137}$ Novak, Thomas and Lowell, supra note 105.

138 Ibid, at 265-6.

139 See Enterprise Income Tax Law of the People's Republic of China (2017), art.41 and Implementation Rules for the Enterprise Income Tax Law of the People's Republic of China, arts. 110-111. The text of both statutes is reproduced in the Appendix of Jinyan Li, International Taxation in China: A Contextualized Analysis (2016). See also Li and Ji, supra note 68; Jian Fan and Yuesheng Jiang, eds. Practical Guidance for International AntiAvoidance [Guoji Fanbishui Shiwu Zhinan], Jiangsu People's Press (2012) (in Chinese) (emphasizing the importance of global value chain analysis).

${ }^{140}$ UN Manual on Transfer Pricing, supra note 75, Heading 10.3.

${ }^{141}$ Richard Vann, “Current Trends in Balancing Residence and Source Taxation” in Pistone and Brauner, supra note 1 , at 391 . 